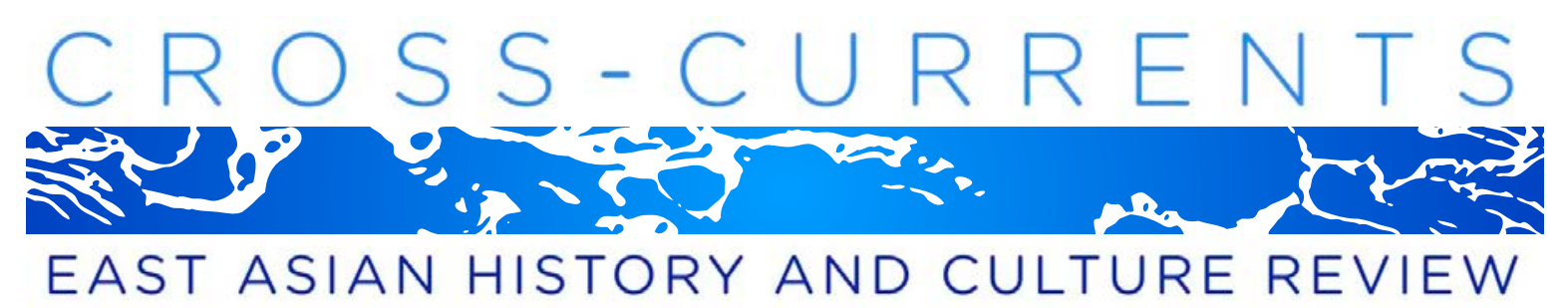

\title{
The Creation of a Nonexistent Group: Sino-Vietnamese Couples in China's Borderlands
}

Caroline Grillot, Max Planck Institute for Social Anthropology

\begin{abstract}
Marriage migration to mainland China has only recently attracted attention in public and academic discourse. Driven by a complex combination of structural and personal factors, many of these marriages remain unregistered, and understanding them requires a different approach than that used to study other international marriages in the region. To date, most discussions have addressed the phenomenon from a legal, demographic, or economic perspective. Considered as illegal migrants, many of the foreign women involved in these marriages are reduced to silence. Based on the specific case of Vietnamese women engaged in de facto marriages with Chinese men in China's southern borderlands, this article describes several factors affecting this social group: the condition of "nonexistence" that the couples experience in their daily lives; the local response to their presence in Chinese communities; and the ambivalent position of governmental bodies regarding their residence and life in China. This ground-level perspective demonstrates how the apparent tolerance of this complex phenomenon may, in the long term, actually create more disturbance in local communities than would be expected. This article reveals how significant gaps between official migration policies and actual practices of governance at the local level limit the social integration of marginalized individuals by sustaining the conditions for their long-term invisibility.
\end{abstract}

Keywords: cross-border marriages, Vietnamese migrants, borderland, China, nonexistence

\section{Introduction}

Each year, tens of thousands of mixed couples (Chinese citizens married to foreign nationals) get married and live in China, and the numbers are increasing. International marriages may generally be divided into two categories. One group consists of those marriages that are highly visible and regarded as a symbol of globalization and cosmopolitanism, phenomena widely evident in contemporary Asia (Toyota 2008; Constable 2009; Jones 2012). Shanghai, with its large expat and mixed communities is representative in this regard. In contrast, the other group of marriages remains largely invisible and occurs in China's borderlands, where encounters with the Other happen during daily cross-border activities and may lead to longterm relationships (Lang and Smart 2002). Thus, a Western man married to a Chinese wife in 
Shanghai does not necessarily have much in common with a Chinese man married to a Vietnamese wife in a mountainous village of Guangxi. In theory, both couples should comply with Chinese laws, register their marriage, and enjoy similar rights. But in practice, this process may be hampered for the second couple by considerable administrative and personal obstacles that ultimately put them in a marginalized position due to the absence of either (or both) formal or social recognition of their relationship.

In her research on Mexican migrants settled illegally in the United States, the sociocultural anthropologist Susan B. Coutin (2003) elaborates on the concept of "nonexistence," which conveys the idea that groups of people are excluded from public life and recognition because of their legal status, even when they apparently live just like others in their community. This concept is also applicable to Vietnamese migrants in the southern Chinese borderlands, individuals whose position constantly oscillates between a tenuousand sometimes denied-social recognition and a perilous legal nonexistence. In this article, I describe the case of Vietnamese women who, as wives or mistresses of Chinese men and as mothers of their mixed children, live in China in an inconspicuous way, whether they are integrated into or segregated from Chinese society. As I show, many of these women live in a condition of administrative or social "nonexistence"- that is, in the vulnerable position of being an unrecognized citizen-which distinguishes them from the rest of the population. My analysis is based on the ethnographic data I collected in four twin cities-Hekou (Yunnan Province) and Dongxing (Guangxi Province) in China; and Lào Cai (Lào Cai Province) and Móng Cái (Quảng Ninh Province) in Vietnam (see figure 1)—and some surrounding villages in the Sino-Vietnamese borderlands between 2006 and 2010, as part of my research on crossborder marriages. Although located in regions largely inhabited by ethnic groups, these cities are mainly populated by Chinese Han who recently migrated from other provinces and are involved in cross-border trade. The scope of my research includes neither the reported human trafficking cases involving women from mountainous ethnic groups (Lazzarino 2014) nor the specific cases of indigenous intermarriages between members of ethnic groups living in neighboring upland communities. ${ }^{1}$ Since the topic of cross-border marriages is regarded as highly sensitive and secretive by local authorities due to its connection with illegal migration, I relied entirely on a "snowball" method among locals to approach mixed couples facing various challenges in their daily life in the borderlands. This research method entailed building a network of acquaintances through the personal connections of an initially limited number of informants, and leaving it up to them to introduce me as inconspicuously as 
required to others whom they felt would be receptive and suitable for my research. The subjects of my study were Chinese men (either Han, or acculturated and urbanized Zhuang ${ }^{2}$ from Guangxi) and Vietnamese women (mostly Kinh, the major ethnic group in Vietnam, and occasionally other ethnic groups ${ }^{3}$ ) directly involved in cross-border marriages. I shared moments of these couples' lives, observed their activities, collected life stories, and conducted semi-structured interviews with them, as well as with members of the communities with which they interacted.

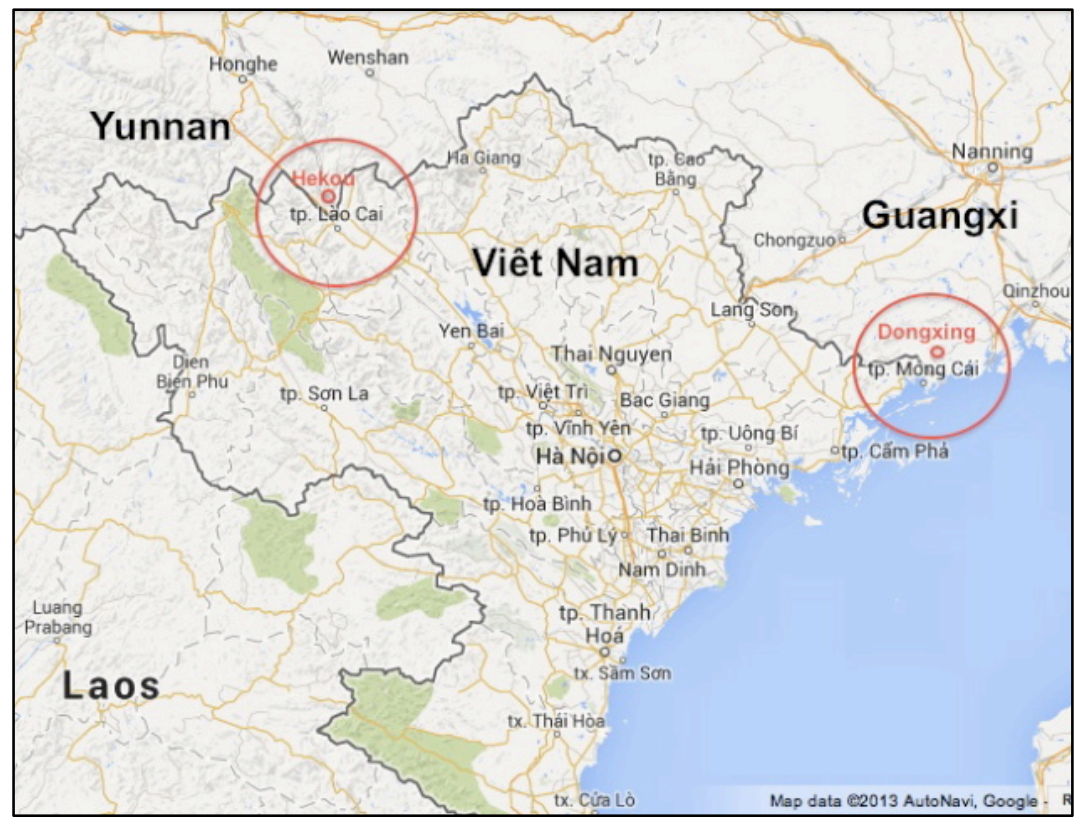

Figure 1. The Sino-Vietnamese borderlands: Hekou and Dongxing in China and Lào Cai and Móng Cái in Vietnam. Source: Google Maps.

Any research conducted in the Sino-Vietnamese borderlands must take into account the centuries-long connections between China and Vietnam that still resonate in the everyday lives of local people. The extensive existing literature on this turbulent relationship describes the complex negotiations that frame political and economic interactions in recent history; some of the literature emphasizes how these tensions are interpreted and absorbed by local actors, whether policy makers or average dwellers (Evans, Hutton, and Eng 2000). Keeping in mind the historical background and the political context in which personal alliances occur today is essential. These include the thousand-year integration of Vietnam into the Chinese empire, the common ground of the two countries' languages and cultures, the 1979 border war, the current economic domination of Chinese trade, and the ongoing dispute over the 
Spratly and Paracel Islands in the South China Sea, to name but a few. These sensitive aspects of the current relationship between China and Vietnam frame the empirical experiences of local people (Womack 2000; Turner 2010). To this day, these neighboring countries are still affected by a prevalent feeling of caution and distrust; this is true both at the diplomatic level and at the level of the general population, despite the extent of economic cooperation that links both sides of the China-Vietnam frontier. It is against this particular backdrop that cross-border marriages have become more visible in the last two decades.

To explain the phenomenon of cross-border marriage that has received international attention for the last two decades, one must first look at local history. Borders have traditionally been porous lands of migration, where people and goods of all kinds have circulated under blurred rules that empires, followed by nation-states, have hardly enforced. Movement was disturbed only by significant conflicts and by colonizing powers that imposed close scrutiny over the frontiers (Lafont 1989; van Schendel and Abraham 2005). After the latest military conflict between China and Vietnam in 1979, the Sino-Vietnamese border reopened in 1991, allowing once again the flow of reuniting kin, traders, and audacious migrants. Following the recent economic development of this region into a nexus of international commercial exchange where border trade is actively promoted, border control has consequently been simplified through various formalities that allow local residents (i.e., native people) to come and go easily over the border and non-locals (i.e. established migrants) to cross the border without going through the tiresome usual procedure required for tourists crossing an international border. Therefore, thousands of people transit through the numerous mountain tracks, local checkpoints, and international border gates along the frontier each day, with or without proper documentation. In this context of intense human interactions, Vietnamese women also come and go, trading, guiding, translating, carrying, seeking fortune, and, in the case of some, selling themselves. Therefore, although the phenomenon of crossborder marriage is not in itself a new feature of local social life, it is now regarded as problematic by the Chinese and Vietnamese states, because it is regularly associated with shady border activities, such as human trade, illegal work, smuggling, prostitution, and various forms of deception on both sides.

\section{Cross-Border Marriages in the Borderlands}

Whether discussed in media reports, international observations, or official rhetorical discourse, cross-border marriages between mainland Chinese men and women from China's 
southeastern neighboring countries, including Vietnam, are typically analyzed and explained in terms of contemporary realities, often without considering their historical and cultural background. These reports emphasize the impact of structural factors, such as the demographic and economic gaps created by socioeconomic reforms to the local marriage markets in both countries and the changing conditions in which private encounters occur. According to many interpretations, a lack of marriageable women in China and better life conditions there have attracted some Vietnamese women to migrate, a move rendered easier since the official reopening of the border between the two states in 1991. But such structural factors have proven insufficient to explain the extent and pattern of the contemporary crossborder marriage phenomenon.

As Coutin states, "The space of legal nonexistence occupied by unauthorized immigrants is... another dimension of a previously entered space of social nonexistence" (2003, 184). Indeed, many men and women who seek social recognition by finding a mate and switching from being bachelors, single women, divorcées, ex-convicts, ex-prostitutes, isolated elderly, or any other sort of social outcast position to assuming the normative role of "married person" may actually enter other realms of marginality. Following Coutin's approach, I have argued elsewhere that the men and women involved in cross-border marriages belong, to some extent, to such excluded segments of the Chinese and Vietnamese populations (Grillot 2010; 2012a; 2012b), positions that economic difficulties alone cannot explain. In the context of intense rural-urban migration, marriage squeeze (the current shortage of women in China due to the one-child policy and selective abortion), increasing gender inequalities, and social disparities that change the negotiation of marriages, yearnings for traditional conjugal ideals and a desire to enhance one's social position also explain the occurrence of these mixed marriages now deemed by many to be valid alternative options. However, stereotyped representations of mixed couples in the borderlands, as well as the ambiguous status that they often hold, contribute to their marginalization in both their native and host communities, in a more or less subtle way.

To address the exclusion and marginalization of alliances between Chinese men and Vietnamese women in their social environment, and more specifically the absence of legal status-the "nonexistent" state-of the Vietnamese women, this article focuses on the situation of those living in urban border towns, drawing on couples' narratives as its primary source of information (Huynh Chau Nguyen 2009). 


\section{Vietnamese Immigrants}

Due to the shared kinship rule of patrilocal residence (at least in the Kinh and Han ethnic groups discussed here), mixed couples in this region-which mainly consist of Vietnamese wives and Chinese husbands-generally establish their homes in China. Additionally, for family, professional, convenience, and economic reasons, Chinese men generally choose to remain in China rather than settling in Vietnam. This necessitates that their Vietnamese wives find a way to move to and stay in China. Their ability to do so largely depends on their native place, their marital status in Vietnam, and their legal position regarding Chinese migration policies. Many Vietnamese women find themselves trapped when they cannot apply for proper registration in China and, in turn, cannot document the reason for their absence in Vietnam. In other words, these special immigrants are unable to comply with the various requirements of Chinese authorities regarding immigration, giving particular weight to the issues of social visibility and administrative existence.

While it is relatively easy for borderlanders to obtain permission to cross the border in either direction, it is more complicated to obtain documents for long-term settlement. Here lies one of the central issues. In China as well as in Vietnam, residential status depends on the possession of a hukou 户口 (household registration; V: họ khẩu), a document that grants its holder important social benefits. In the borderlands, people are classified as native or provincial (i.e., either born in the frontier regions or coming from the inner provinces of either country). To obtain the right to cross the border into China, a Vietnamese citizen has to provide the local Vietnamese police with his or her hộ khẩu. According to the regulations in Móng Cái, for instance, a native from Quảng Ninh Province can apply for a giấy thông hành xuất nhập cảnh-locally called a bianmin zheng 边民证 (borderlanders' pass) and officially called a churujing tongxing zheng 出入境通行证 (immigration permit). This permit features both languages on the front cover, is valid for three months, contains sixteen pages, and costs VNĐ 30,000. ${ }^{4}$ Nationals from any other province can apply for a giấy thông hành nhập xuất cảnh-locally also called tongxing zheng 通行证 (travel pass), which is valid for one year, contains twelve pages, and costs VNĐ 250,000. ${ }^{5}$ To obtain this document, a Vietnamese migrant living in the borderlands needs to provide a giấy phép cút trù tâm thời (temporary residence permit) or pay a travel agency operating on the Vietnamese side if he or she does not live regularly in the border town. Each of these documents allows its holder to cross the border and stay in China for three days. The next step involves another procedure at the Chinese police station. A Vietnamese citizen may apply for a giấy phép cứ trù (residence 
permit; C: juliuzheng 居留证) that allows him or her to stay in China for up to three months. Obtaining such a document seems to be possible if one can provide a valid "travel pass." However, these travel passes allow one to stay only in the strict periphery of the borderlands. Traveling further inland requires a passport and a visa. Controls at various checkpoints on the roads that link the frontiers to the rest of China ensure that Vietnamese migrants possess the required documents. Of course, despite these legal procedures, countless Vietnamese migrants enter China in the interstices, reside there without paperwork, and manipulate the immigration rules. This is where one finds many Vietnamese women living in a space of nonexistence.

The administrative position of Vietnamese women has become a serious concern for local authorities facing the settlement of these outsiders in their territories. One can identify three general administrative profiles among the Vietnamese women who live in the SinoVietnamese borderlands with local Chinese men (beside workers and prostitutes), regardless of their ethnic background and living location. ${ }^{6}$ On the one hand, there are those who are officially married, or are in the process of registering their marriage with a Chinese man, and live legally in China; like any other foreigner married to a Chinese citizen, these women have passports, visas, and residence permits to stay in China. On the other hand, there are the women who entered China (legally or not), ended up as the de facto wives of Chinese men, and settled there. They do not meet the conditions necessary to apply for documents and therefore remain officially invisible. Between these two common situations are those women who lack a life plan and find themselves in a transitory or vulnerable position: they live with Chinese men, for a temporary or long period of time, but because their private lives and residential statuses are too unstable, they cannot be granted a long-term residential permit.

The question of status and citizenship remains problematic for the last two categories. These Vietnamese women may live in an isolated place in China where they enjoy no administrative support or rights. They may also be engaged in trade or service activities in the urban settings of the borderland that offer them opportunities to develop social networks. They either stay on in China with temporary permits, which forces them to constantly go back and forth to Vietnam, or they manage to escape official inquiries and stay for a longer period of time, although technically illegally. But in all cases, as long as their relationship with their Chinese partner is not officially recognized, they remain in a vulnerable position, subject to many sorts of abuse. 


\section{Between Formal and Informal}

There are various obstacles to formalizing a union between a Vietnamese woman and her Chinese companion. Most result from the tension between legal procedures and local marital practices, since the practices of bureaucratic culture vary from one country to another. Several factors might interfere with the way a couple copes with its situation. The origin of each spouse (whether or not he or she is a borderlander or an innerlander) comes first. The distance between the place of residence (border settlement or other location within China) and the place of household registration is crucial. Indeed, Vietnam and China have similar administrative systems: marriages must be registered where the hukou was issued. This requires that the couple invest time and money to travel to either one of the spouses' native locations together. Such a system makes marriage formalization equally difficult, whether in Vietnam or China. A second concern involves the conditions under which the Vietnamese woman entered China, specifically whether she possesses a travel pass or not, and thus whether she needs to apply for further documentation. Does she have a temporary or permanent residence permit? Has she been staying in China illegally? For how long? Moreover, the spouses' marital status outside of their current relationship is crucial and is cited in many of the observed cases as a significant obstacle: Was the prospective husband or wife initially single, already married, separated, or divorced? Does he or she have the legal right to get married? On a more personal level, the nature of the relationship that the couple maintains is also a factor: Is the union agreed upon or forced, arranged, permanent, temporary, or dependent? Does the couple have children or not? Do they actually live together? For many couples, these questions have remained unresolved and the initial relationship has become a de facto one with no intention or possibility of becoming official.

The fact that many of these couples are migrants living far from their extended families offers some relief from the judgment and pressure they would face if they were living under the obligation to fulfill filial duties and provide their parents with the guarantee of a long-term engagement. Their administrative invisibility exacerbates the distance they have already established, voluntarily or not, from their initial family and social network. But it also deepens the importance they place on the formalization of private matters. In Vietnam, for instance, weddings are frequently celebrated without being immediately followed by administrative registration. Registration may be delayed a few months, or even a few years, before the need for documentation becomes urgent and forces a couple to make their marriage official. Since the enactment of the 1986 Marriage and Family Law, ${ }^{7}$ single mothers 
are recognized and their children are legally legitimate. It is therefore possible to register the birth of a child on a mother's hukou without penalty; the administrative procedure for marriage registration often takes place when a couple registers their child at school. This means that in Vietnamese society, it is common to see children officially recognized as single mothers' offspring until they reach school age, when their parents proceed to apply for marriage registration. This legal condition allows for a relative graduation of marriage registration that is embedded in the sociocultural practices of contemporary Vietnam. By contrast, the wedding ceremony remains the most important celebration: it socially sanctions the commitment of two persons and two families to each other. It is the most meaningful expression of acceptance of a relationship, even though from a legal standpoint, such unions remain invalid without proper registration. This gap between informal social recognition (through a wedding banquet) and legal formal registration (through proper paperwork procedures) resonates even more in the case of "international marriage," although this may not be the exact vernacular term used to designate what is viewed as a marriage between neighbors, members of a similar ethnic group, or kin separated by historical upheavals and blurred territorial frontiers. According to comments from borderland residents, cross-border marriages require even more validation than other unions to be accepted as sustainable relationships, since they challenge cultural unity and involve risks of misunderstanding and vulnerability.

For the majority of the Chinese and Vietnamese populations, going through the bureaucratic procedures in their socialist administrative systems is often considered a waste of time and money. Thus, they tend to avoid formalities as much as possible unless they feel forced to comply with official requirements. In the specific case of marriage registration, local people's limited knowledge of the complicated procedures regarding international marriage causes them to neglect basic regulations and pursue their family project according to customary practices. Unlike those couples who get married through a broker agency, as in the case of urban areas where international marriage has become an industry (Yang and Lu 2010; Wang and Chang 2002), populations in the borderlands receive minimal guidance. Due to the generally condescending and dubious public view on these marriages, and the issue of illegal migration and offspring that complicates the picture, Chinese civil affairs authorities do not make much effort to advocate for the recognition of these particular mixed couples. Therefore, couples are often discouraged when they do seek relevant information from various local administrations. This is especially the case when the relevant offices are located 
in remote areas where the occurrence of marriage with foreigners is scarce and local civil officers are unprepared to tackle the related procedures. Unless couples decide to directly seek diplomatic representation (at the Vietnamese consulate in Kunming or Nanning, or the Chinese consulate in Hanoi) to proceed with the required paperwork, or to search for information on the Internet (for those familiar with such tools), local civil officers are (supposed to be) the only experts who can provide them with relevant information. But for those migrants who do not have a standard immigration or residence status, entering an official building already represents a difficulty, which they try to avoid. Hence, many couples rely on the experience of acquainted married mixed couples to take action-in the best case scenario-or choose to simply ignore the laws, remain in a common-law marriage, and give up any form of regularization... at their own risk.

Even for those who do possess the correct information on the procedure to register an international marriage, doing so still represents a complex, long, and costly path, given the character of the border population. As mentioned above, when Vietnamese women and Chinese men meet in urban settings in the borderlands, many of them are already migrants who have come a long way from a distant province to work, trade, and settle in these promising centers of development. For a couple that decides to get married legally, this means that they need to travel long distances in order to gather the documentation, stamps, and authorizations needed to apply for a marriage certificate: birth certificate, hukou, certificate of celibacy, and health check-up, among others.

Ly, a young Vietnamese woman from Móng Cái, got married to her Chinese husband in 2006, after months of hesitation. She describes the complex procedures they faced, in addition to their families' disapproval:

The procedure was long, but what I hated the most was the suspicion local officers expressed. My husband is much older than me, is from a minority group, and had never been married, so when the officer from the foreign affairs office in Hanoi interviewed us, he suspected that our love story was not genuine. This was very annoying, even humiliating! Why would we have traveled such a long way to get interviewed if our marriage was not real? But we needed their approval to proceed with marriage registration. We had to go several times because they were not convinced by our explanations at first.

In a way, Ly was lucky, because her husband's hometown was not far from the border and he could easily visit the local offices. Prospective spouses need to go to several administrative centers, mostly provincial cities, in order to obtain the requested documents or the precious stamps: police offices for the hukou and local registration of residency, the civil affairs 
bureau for non-married or divorced certificates, the foreign affairs office for an interview, consulates for validation of marriage certificate and visas, and so on. Sometimes they must show up, get interviewed, and check out several times before their application is approved. For many, irregular situations regarding the residential status of the Vietnamese wife, recurrent suspicion concerning the consent of a union, or family disapproval are additional obstacles that delay registration and challenge the patience, intention, and budget of prospective spouses.

Regional variations also add to the confusion. Many couples emphasized the variation of the specific order in which actions should be taken, as well as the duration, possible complications, and considerable fees involved (including administrative fees, transportation costs, and bribes). All of this on top of the fact that being able to travel together to these different places already requires proper travel documents, such as a passport and visa, which many Vietnamese and Chinese living in border towns do not have, since they can rely on specific permits to work and live in the borderlands.

This unclear and costly process prevents many de facto couples from starting such a bureaucratic journey. Hence, many simply ignore regulations and remain unregistered, in limbo, for years or even decades, after which time some couples give up any attempt to legalize their relationship. In some cases, the controversial personal trajectories of the spouses, from the local community's perspective, impose and motivate them to keep a low profile in the community to avoid scrutiny.

When she was a teenager, Yên was taken out of school by her father, who had promised her to a man she did not love. She was in love with another man and opposed the arrangement, but eventually she was forced to accept the marriage. After a year, she divorced her husband because he had cheated on her (he claimed that she could not bear children). She was twenty-two years old and had had several miscarriages by then. Over the next nine years, she rejected all suitors, saying she hated men, and devoted herself to farming. However, after hearing rumors that Chinese men were better husbands-more protective, responsible, respectful, and helpful—she pursued the promises of a matchmaker. Only after arriving in China, in a village near Dongxing, did she realize she would be sold. She was pledged to Wang Shao, a retired teacher thirty years her senior. Shunned by local villagers because of his family background (as a member of the "black class," according to the Maoist categorization of the population) and a divorce that ruined his reputation, he maintained a very modest life. When he heard about Yên's misfortune, he negotiated with her captor to 
quietly release her for an undisclosed amount. Concerned and respectful, Wang Shao offered to give Yên money to return to Vietnam, but she refused. Touched by his kindness, Yên offered to stay with him, but he initially refused, citing their age difference. Yet, fifteen years later, they have become an accepted couple, although their relationship has never been legitimized. Yên lives in the village, although she does not have any documentation. She is financially independent since she works in a factory, although she does not have a permit, and Wang Shao continues his simple life. He has taught Yên the Chinese language. He says he now has to decline offers from Chinese women who are suddenly interested in his retirement pension, which they do not like to see shared with a foreign woman with no status, suggesting that after he dies Yên will not be eligible for his inheritance and the money would be lost unless Wang Shao remarries a Chinese citizen.

Yên, whose trajectory shares many similarities with that of other Vietnamese women, remains in a vulnerable position. She works - without a contract-and lives in the borderlands, but she has no official existence in either China or Vietnam. She participates in local life and the local economy without being acknowledged as a person. She's a wife without any legalized tie with her husband. In the case of Sino-Vietnamese cross-border marriages, Vietnamese women are the ones who actually migrate to live with their husbands and must face the most serious administrative challenges - in both countries-of their chosen or imposed situation. They need to obtain recognition of their status as spouses and mothers of Chinese citizens' children and risk the most if they are caught in an illegal position in China.

\section{Is Legal Existence Negotiable?}

When Vietnamese women illegally enter China without a passport, visa, or permit and live there for a while, returning to Vietnam becomes a complicated prospect. Many hesitate to return to their hometowns if they are unable to provide family and friends with gifts or remittances of some kind. Huyen is the Vietnamese widow of a Chinese fisherman in Wan Wei's village, a few kilometers away from Dongxing, which is also home to numerous Vietnamese wives (Nguyen 2014). Despite the proximity of the border and the connections she may have to help her cross the border without a permit, ${ }^{8}$ Huyen admits that she has never returned to her hometown to visit her family or resettle with her children in her country. Poor, but not to the extent of being unable to afford a bus ticket to get to one of the local smuggling border ports, Huyen's reluctance to leave reveals the real obstacle she faces: her inability to 
return home with dignity - that is, with presents for her family, positive news about her situation, or any signs of significant social or economic success. As with many other women I met in this region, for Huyen, marrying a Chinese man did not bring the upward mobility she expected, or even an improvement of her initial life conditions. Hence, returning to her hometown simply to do paperwork has subtle and contradictory social implications for a Vietnamese wife. Offering the impression of either success or failure conditions the ease with which one might approach one's community again. For some, the benefit of obtaining a certificate is not worth the risk of altering their social position and their family's reputation. In Vietnamese communities, marrying a Chinese man may be perceived as the result of coercion or the ultimate way to leave sex work; in any case, the social stigma attached to such a union makes it a disgraceful act. But it can also mean marrying up and the promise of a better future, and hence be a promising act. In any case, registering a marriage (by acquiring documentation) exposes a woman and her family to commentary: in a Vietnamese village, the return of a woman and her negotiation with local officers rarely goes unnoticed. Therefore, the reluctance to request documents from the Vietnamese administration finds its roots in a protective instinct toward one's family, but it can also be attributed to the implications of the act. Indeed, when a young woman leaves her village without informing her family and acquaintances of her whereabouts for a long period of time, she stains her family's reputation. One Vietnamese woman told me that, fearing gossip about her long absence (after she had been lured to China and sold), her family would rather pretend that she was dead than endure the shame of a bad reputation. When this woman eventually managed to return to Vietnam to visit her family, she was told to leave and go back to China, because her "existence" would alter the face her mother had managed thus far to preserve. Under such circumstances, had this woman wished to legalize her Chinese marriage by visiting her village's civil affair office, doing so would obviously have carried too much weight for her to simply show up publicly. Other similar stories indicate that the marriage registration procedure, especially for Vietnamese women who come from small communities where social networks are inescapable, represents a difficult project to undertake.

A Vietnamese woman whose marriage to a Chinese man was the consequence of having been lured, or of "choice by default" (for instance, being sold as a wife rather than as a prostitute) reveals another administrative issue. Being absent for a long time (i.e., over six months) without notifying the Vietnamese local administration generally means that one will soon lose one's civil rights (Peters 2002). In Vietnam, if a person does not or cannot inform 
his or her family, community, and civil authorities of an intention to migrate, whether for a short or long time, and especially when going abroad, he or she will be removed from her family's hộ khẩu. This registration system is also aimed at controlling people's mobility; the individual will lose his or her rights and risk the payment of a fine to recover these rights when reappearing and requesting any family-related document. Indeed, Article 32 of the Law on Residence ${ }^{9}$ stipulates that citizens who migrate must declare their absence at their place of residence; otherwise, they shall face the "deletion of permanent residence registration" (Article 22) - that is, they shall consequently be declared as dead, missing, or settled abroad. In addition, even when an individual has registered at a migration destination as a temporary settler, Article 30 also stipulates that "for persons who have registered their temporary residence but do not live, work, labor, or study for six months or more in the localities where they have registered their temporary residence, the agencies which have granted the temporary residence books shall delete such persons' names from the temporary residence registers."

Although the Vietnamese women interviewed for this study often had no intention of staying in China, many of these technically illegal immigrants ended up losing their administrative status by becoming undocumented migrants in Vietnam without any guarantee that they could gain official recognition in China. Many informants explained how difficult it was to regain their rights once they managed to return to Vietnam after escaping an unhappy marriage or visiting family. The Law on Residence does not specify if and how one can recover one's registration in a household after one's name has been removed, but collected narratives and other scholarship suggest that it is always possible to "negotiate the state" (Hardy 2001). Given the acknowledged degree of corruption in Vietnam's administration, these women also mentioned the lack of financial means as an obstacle to negotiating and making arrangements to recover their status and then apply for the necessary documents for a marriage certificate. Hence, the adjustments that well-rewarded local authorities may consider from case to case - the multifaceted regulations themselves—create the condition of existence or nonexistence of national citizens.

On the Chinese side of the border, undocumented immigrants cannot expect to be granted the right to live in China without a proper marriage registration or work contract. But Vietnamese women who, for instance, find themselves in the delicate position of entering China unwillingly and illegally rarely find the means or people's attention to complain or try to seek help, at least not in an organized way (Li, Luo, and Long 2006). Like their fellows in 
other countries of the region, they generally resist Chinese policy passively and remain in the shadows of the local society, stuck in a stalemate, feeling that they are not entitled to any rescue or protection (H.-Z. Wang 2007).

Mai, the Vietnamese wife of a Chinese petty trader, is the mother of two boys. When I met her in 2007, she had lived in a Guangxi village, and then in the Dongxing area, for eighteen years without any marriage certificate. Although her sons had been registered on their father's hukou in exchange for the payment of a fine, she remained in a "nonexistent" position, enjoying no legitimized ties with her children. She worked in Dongxing as a translator in various shops visited by Vietnamese tourists, she lived in China with her family, yet she enjoyed no rights or protection and possessed no documents for more than two decades:

In 1990, after I weaned my first son, I fell pregnant very fast. I had decided to go back to Vietnam to see my family. I left my son in the village where we lived, and my husband accompanied me to the border in Dongxing. We took a bus. We both carried some cash with us. When we reached Nasuo [a checkpoint on the way to Dongxing], someone found out that I was Vietnamese, was going back, had money, and didn't know my way. The person denounced me. The bianfang [边防 border defence] officer took all my money because, of course, I didn't have any ID. My husband gave me his money, and I returned to Vietnam for a few days.... In eighteen years in China, my identity has only been checked once at home [in the Chinese village]. I asked to normalize my status, but the police officer refused to legalize my marriage. He threatened to repatriate me to Vietnam because I didn't comply with the immigration law. So I asked him: "Don't you want to legalize? Do you want to raise my children? If you send me back, there will be two more Chinese orphans in China. Do you want Chinese children to live with no mother to take care of them? If you send me back, I will come back for them." He eventually let me go and that was it. How could he respond to my argument?

Mai's negotiation for her residential rights is an example of the overt tactics Vietnamese migrant women who are settled in China may use when they confront Chinese authorities. Indeed, Mai could have gone back to Vietnam, like many other migrants do to satisfy the agents of state power, and then returned to China in a few hours' time to resume her daily life. ${ }^{10}$ This kind of occasional incident underlines how Mai's legal nonexistence actually remains unexposed and mostly forgotten in her daily life. As Coutin remarks,

On a day-to-day basis, [migrants'] illegality may be irrelevant to most of their activities, only becoming an issue in certain contexts, such as when changing jobs, applying for college, or encountering an immigration official. The undocumented thus move in and out of existence. Much of the time they are 
undifferentiated from those around them, but suddenly, when legal reality is superimposed on daily life, they are once more in a space of nonexistence. The borders between existence and nonexistence nonetheless remain fuzzy and permeable. $(2003,186)$

Several Chinese residents in Hekou and Dongxing also explained how, when bilateral political tensions impose a more severe enforcement of border control, Vietnamese people with illegal status all cross the border back to their native land, waiting for things to return to "normal," their own "normality" being a nonexistent position. However, their own perception and acceptance of this position may not necessarily match the mood of their social surroundings (besides their husband). Public discontent always seems to remain in the background of human interactions in this regard, promptly showing up when it needs a scapegoat for social disorder. The frequent media reports on Vietnamese brides who have run away from their Chinese families with cash and children only to reappear in another location with the same intention in mind sways public consciousness and arouses suspicion regarding undocumented migrants' opportunism, a discourse that is also widespread in Taiwan (Hsia 2007).

The recurrent diplomatic friction between China and Vietnam has an impact on local trade, a crucial aspect of border life that local communities strongly emphasize and complain about. But national conflicts also remind illegal migrants, such as Vietnamese wives, that their nonexistence is a created position that needs to be justified on a daily basis and is virtually inescapable as long as no agreement can be reached regarding their cases. Quite similar to the fear that Chinese traders in Vietnam arouse in times of dispute, although on a different scale and with a different degree of impact, the mere "existence" of Vietnamese women within Chinese society serves as a cautionary reminder of the ambiguous political agenda that both countries embrace, while their nonexistence is evidence of the threat they might represent in case of real conflict. Abandoned by both states, these women rely on life tactics to sustain their vulnerable position, with little hope and support from the authorities.

\section{Between Authority and Empathy}

In addition to each couple's willingness to comply with the laws, the question of marriage registration is linked to two things: the information available (to both couples and local officers), and the way legislation is enforced locally (with possible adjustments). Here, Chinese authorities face a dilemma, especially in the case of the borderlands, where 
international marriages are often the object of suspicion and very much connected with the ongoing activities of border trade and economic migration - that is to say, smuggling. In reality, Chinese authorities are caught between several issues regarding cross-border marriages. Authorities need to promote cross-border trade to develop the local and regional economy. In this regard, mixed couples play a significant role, as they serve traders' interest in creating a network abroad. At the same time, Chinese authorities try to control and regulate migration to discourage the long-term settlement of undocumented migrants. And, finally, they must also acknowledge cross-border marriages that respond to a regional demand for wives and may solve social problems. Still, they deter registration by rendering the bureaucratic process blurry and complicated, and they scrutinize reproduction, which falls under the marriage law $^{11}$ and the one-child policy. Therefore, there is a certain gap between what the central law requires and the way it is locally implemented, resulting in two emerging tendencies at the ground level: tolerance and repression.

Central Chinese authorities have a very delicate role to play-apart from repressionwhen dealing with these mixed relationships, particularly once the couples have children. Therefore, in many rural and semi-urban settings of the Sino-Vietnamese borderlands, Chinese authorities vacillate between two possible behaviors that have various impacts on local social life. As legitimate representatives of the state, local officers and agencies (such as family planning and public security) tend to scrupulously implement the rules, and they search for undocumented couples. They repatriate illegal migrants, search for unauthorized pregnant women, and impose significant fines for breaking the laws. Ironically, when denouncing the illegality of Vietnamese women's residence and ruining local families' lives and hopes, they may also legitimate their actions in the framework of anti-trafficking programs operated by the cooperative Sino-Vietnamese alliance (Y. Wang 2005). By deporting Vietnamese women back to Vietnam, emphasizing their vulnerability and illegal status, regardless of the complexity of each case and the difficulty of applying a concept such as human trafficking to these marriages, Chinese authorities hide the fact that such measures have proven ineffective at combatting human smuggling of all kinds and have generally failed to provide good social conditions to the "returnees" (Bélanger 2010; Bélanger, Hong, and Duong 2007). It goes without saying that many of these women find ways to return to China anyway, both for the sake of their children and because reintegration into their communities in Vietnam turns out to be too complex to initiate (Vijeyarasa 2010).

At the same time, Chinese authorities may also tend to tolerate these mixed marriages 
and sometimes adopt a compassionate and compromising attitude toward them, providing a space between rules and practices - regardless of central regulations-that allow cross-border families to remain united under various conditions negotiated between the parties: payment of bribes, imposed low profile in the community, close surveillance, and so on. This is particularly the case when those in charge of implementing the central policies are members of the community and know perfectly well the concerns of the couples, who are sometimes relatives, schoolmates, friends, or acquaintances. They feel sympathetic toward families in despair, especially in rural settings. Hence, the dilemma of local administrators accommodates itself to a complex web of social networks, in which a representative of the law must choose between going against central regulations or going against the local network of social connections. It is an awkward position to negotiate, which has led to all sorts of compromises and an uneven status quo.

\section{The Second Generation}

The situation becomes even more complicated when a child is born. In theory, the status of a mixed child should be the same whether one of his parents is an American or a Vietnamese citizen, living in Shanghai or in Dongxing. But in practice, unfortunately, it is not. Since Chinese law does not recognize dual nationality, many foreigners married to Chinese citizens choose to give their child foreign citizenship and apply for a passport. In this case, they do not register their child on a Chinese hukou; hence, mixed couples are not subject to the one-child policy. Many cases have proven that, in fact, the interstices of rules allow for adjustment, as well as complications. ${ }^{12}$ However, for a Vietnamese, the situation is different in practice. Being a Chinese citizen is (to them) comparatively more desirable than being a Vietnamese citizen, in terms of quality of health care and education. Besides, Vietnamese women tend to consider children of cross-border marriages to be Chinese, because the father is Chinese. Hence, most Sino-Vietnamese couples choose to give birth to their first child in China, and to get a birth certificate and register the child on a Chinese hukou. If they do not have a proper marriage certificate, this can only be done by exploiting connections or paying a fine for producing an unplanned, out-of-wedlock child (Greenhalgh 2003). When a second child is on the way, the couples often adopt another tactic: they may register the child on his Vietnamese mother's hukou. This prevents the parents from paying a fine for disobeying the one-child policy and the marriage law, but it also allows them to provide the child with a legal status, since Vietnam does recognize children born out of 
wedlock, protects the mothers, and does not limit the number of children each woman can bear. Articles 30 and 32 of the 1986 Marriage and Family Law clearly establish that

recognition of a child born out of wedlock shall be attested and recorded in the Birth Register by the People's Committee of the commune, city ward, or town where the child resided ${ }^{13}$ [and that] a child born out of wedlock who has been recognized by his father or mother or by the People's Court shall have the same rights and duties as a child born in lawful wedlock. ${ }^{14}$

Each couple hence considers the best strategy according to its needs and the degree of agreement they can reach with each other regarding matters such as whether they want to stay in the borderlands, move to China, or give their child a Chinese education. But, in practice, complications may arise at various stages of their plan. Zhang is a middle-aged Chinese businessman in Hekou. He manages his brother's hotel, while his wife manages two brothels:

I came from Guangxi and arrived in Hekou in 1990. I met my wife in 1995, and we have been living together since. We only got married in 2004. My hukou was in Guangxi, and she could not go there to get married with me. So we waited until we could buy an apartment in Hekou and then transferred my hukou here. Then, it was possible to do the formalities. We had our son in 1999. But theoretically, we couldn't have a second child. We paid to buy a hukou for her in Guangxi [using personal connections]. She has never been there, but she is considered a Chinese woman from Guangxi now. This means that she must comply with the one-child policy, as I do. However, we do have a second child now. We had to pay 3,000 yuan to register the first one on my hukou. In 1999, my wife was still officially Vietnamese, and we were not married, so our first child was considered born out of wedlock. According to what we have been told, we would have to pay 78,000 yuan now to register the second. This time, the fine is for being born out of plan.

A Min, another Chinese man established in Hekou, also shared the tip he used to thread his way through the family planning policies (the "fake adoption tip" widely used among ordinary Chinese couples):

My wife and I have lived in Hekou for four years. She had just arrived in China four years ago when I moved here from Hunan. I am thirty years old and she is twenty-two. We have a six-month-old baby boy [born in March 2008]. We are not registered. Before, I was working on the casino boat, and I had been arrested and fined. For this reason I can't have a passport. I've registered my son on my younger brother's hukou. He has a rural hukou that allows him to have two children. He already has a daughter. My son is officially his second child. 
The decisions made at the stage of parenthood say a lot about gender imbalance, as well as about the prospects each couple imagines for the future. In many cases, when the child is a girl, couples tend to register her in Vietnam, while boys are more likely to be registered in China. Men tend to be more committed to securing their child's status when they have a son. A registration in China means that a father can have greater control over his child's school, health, and so on. If a child is registered in Vietnam, the responsibility for the child falls on his mother, while the father is excluded from any official role. The complex position into which mixed couples are put when facing their responsibilities as parents also reveals the level of trust and the importance of family pressure on the couple to secure a child's future, whether in China or in Vietnam.

\section{Exclusion Comes from Categorization and Perception}

Among the many real problems that mixed families face are marriage registration, access to Chinese citizenship, permanent residence rights, health care, children's nationality, and the right to an education (Luo and Long 2008). But the problematic status of Vietnamese women, especially when labeled as feifa yimin 非法移民 (illegal migrants) or guaimai renkou 拐卖人口 (trafficked people), represents a threat to the Chinese nation-state, according to official discourse. Vietnamese wives also stand between different categories, according to which discourse one considers. By representing an abnormality in the realm of migration, conjugality, and social welfare, cross-border marriages threaten normality and are considered conceptually polluting. In popular narratives, Vietnamese women are not represented as victims of strict bureaucracy, unscrupulous men, or a poor economic environment. On the contrary, they are often seen more ambiguously, as hiding a secret agenda: they may steal Chinese money or the husbands of Chinese women, or allow Chinese men to satisfy their sexual needs in exchange for various advantages (i.e., being a concubine). The integration of Vietnamese women into Chinese society through marriage will remain limited as long as local negative perceptions about them circulate, and as long as their relationships are not sanctioned by communities, families, and the law.

The main issue is that, so far, there has been little opportunity for many cross-border families to escape from such an ambivalent position, deriving as it does primarily from their communities' perceptions. Over the long term, this dynamic gives rise to social fringes. These individuals become people who live in a state of legal nonexistence for an unlimited period of time under vulnerable conditions. These conditions lead them to adopt tactics to 
respond to the changing environment that potentially threaten their already insecure position, and, in extreme cases, lead to social exclusion. Many of these couples ${ }^{15}$ tend to stay in the borderlands, a unique space that provides them with the conditions needed for evasion. Hekou and Dongxing represent such flexible spaces: in case of problems, migrants can leave, cross the border, return to their hometowns, become visible in their own spaces (with the limitation that the loss of household registration implies), reconnect with their previous lives, or indefinitely remain on the fringes of Chinese or Vietnamese society. Others prefer to stay inconspicuous in rural areas or to obtain fake IDs further north in China to avoid being seen as dissatisfied Vietnamese women escaping; in this, they are encouraged by their Chinese husbands, who, more than anyone, would prefer that their communities forget about their wives' identities and allow them to maintain a respectable social position.

\section{Seeking Existence in the Manipulation of the Law's Interstices}

The position of these Sino-Vietnamese couples is also intertwined with the hukou policy and its changes. As mentioned above, there are families who manage to get around the legal requirements through family planning and registration of marriage and birth. But this very much depends on their financial means. One strategy, for those Chinese husbands with significant incomes, is to transfer their hukou from their birthplace to their new settlement in the borderlands. According to some informants, it was possible until a few years ago to essentially buy a hukou from the place where one intended to establish residency status. ${ }^{16}$ Apparently, the law has changed on this particular point and this is not possible anymore. Nowadays, the practice for most people who wish to move their hukou from their native location to their new living place (in the context of permanent migration) is to buy property in the new locale. In both cases, the hukou's transfer eases the formalities regarding family status and rights and allows border people, for instance, to arrange marriage registration more easily, since they do not want to invest their capital in traveling all over China or Vietnam to get a stamp or an appointment with an official. However, the formalities remain the same and documents from both sides are required. If a Chinese man transfers his hukou to Dongxing, for instance, it eases things for him. But his Vietnamese wife still has to return to her hometown to get her own paperwork done. In any case, because of the cost involved and its consequences in terms of commitment, a marriage registration through property investment and the transfer of hukou is not a realistic option for many couples. 
The very category of marriage also means different things to some Chinese men. In the borderlands, many men who live with a Vietnamese partner are recent migrants who do not necessarily intend to spend their lifetime in a border town, and do not wish to move their hukou there. They may be temporary workers who own land and have extended families back in their village; they may be entrepreneurs who endeavor to establish a business with Vietnam; or, they may even be locals who seek a convenient relationship with a Vietnamese woman. But the issues of residency, caring for parents, and personal reputation are factors that they all need to take into consideration before making the decision to officialize a relationship that could easily stay casual and pragmatic, especially given the amount of gossip and scandal surrounding cross-border relationships. For some of these men, who are aware of the unpredictability of border trade, it may not be worth sacrificing the administrative position their hukou provides them back home for the sake of a marriage that often involves a degree of uncertainty—as many local examples attest—despite personal feelings and the existence of children. These men choose to maintain more convenient access to other sorts of benefits in their hometown (such as education for their children) instead of securing their wife's position. It is a question of priorities.

So, to avoid inviting the Chinese state into their private lives, some couples explore other ways of manipulating the interstices of laws and regulations to obtain, protect, or maintain a status, either legal or social. Chinese husbands may buy fake IDs for their Vietnamese wives and a fake marriage certificate to register them on their Chinese hukou under a false identity; they may adopt the Vietnamese children of a previously married woman; and so on. But for those Vietnamese women who do not have a chance to regularize their status even through such procedures, who do not get support from their husband's family, for instance, their marginalization increases. This position jeopardizes their mere existence as (any) citizen and thus deprives them of rights anywhere, leaving them in a state of profound vulnerability, yet enhancing their survival skills.

\section{Conclusion}

The case of Sino-Vietnamese marriages illustrates the variety of international marriage in mainland China. This article examined factors affecting the status of SinoVietnamese marriages in general, and Vietnamese women in particular, in the semi-urban context of the Chinese borderland. The Vietnamese wives' nationality, the way they entered China, their intent—whether the marriage was a deliberate choice or not—and their official 
behavior concerning their situation all eventually decide these women's legal and social fates. For those who cannot meet the administrative requirements for marriage registration, remaining inconspicuous in Chinese communities and avoiding scrutiny by the authorities quickly result in a life of nonexistence. Officially uncontrolled for being an illegal migrant, or at best always on the move with temporary documentation, for working without a contract or protection, or for bearing children without being legally recognized as a mother, Vietnamese women experience the vulnerability of a relationship that is supposed to bring them security and well-being. Many women express their fear of being neglected, or of being denied any rights to their children if their husband suddenly decides to end their relationship or to return to his hometown (without a wife who does not have travel documents), or if his family refuses to accept the responsibility of having an illegal migrant in their household.

Generally, state governance of cross-border marriages creates the condition of nonexistence by allowing the phenomenon to spread and by ignoring these marriages and failing to provide realistic options to legitimize the situations of families that do not fall into conventional categories. Chinese authorities are caught between an implicit acknowledgment of the importance of a cross-border network that includes families and the need to monitor migration and discourage long-term illicit settlement (Li, Luo, and Long 2007). The condition of nonexistence is the result of contradictory regulations and perspectives that may emerge from the inconsistent political agendas of different levels and offices in charge of controlling the borderlands population. As I have argued, the consequences of unassistedrather than uncontrolled-immigration for Vietnamese women engaged in a common-law marriage with Chinese men may be summarized as follows: They face the loss of their rights in Vietnam without gaining new rights in China. They rarely manage to register their marriage and obtain legal protection. They benefit from no assistance or integration program when they enter China illegally. Because they have few options to secure their position and their future, they may use illegal ways to integrate into Chinese society and thereby take another step into illegality. And, finally, they face the risk of various forms of exploitation, vulnerability, and insecurity in the context of their professional activities, family life, and interaction with local Chinese communities. In a way, these Vietnamese women and sometimes their children share the plight of another social category in Chinese society, unauthorized children (Skalla 2005): an "outcast group of unplanned, black persons who, as legal non-persons, exist on the margins of society, lacking citizenship rights and state benefits" (Greenhalgh 2003, 196). 
Nowadays, the ambiguous meaning of the term "cross-border marriage" reflects how the notion of legality, in its lived or empirical sense, has lost most of its significance in the context of the borderlands. Migrating and marrying across a border is not about conveying or adopting a Chinese or Vietnamese identity or way of life; it might simply be about yearning to be part of a couple, part of a normative structure or conventional pattern of family in societies that are strongly structured through marriage. Without entirely achieving the passage between singlehood and marriage with legal recognition, receiving no support from the concerned authorities, those in cross-border marriages remain marginalized, with no guarantee about their future as individuals or as part of a family, and hence "nonexistent," a barely sustainable position. And for migrating Vietnamese women, this can signify switching from being an existing social outcast in Vietnam to becoming a nonexistent subaltern individual in China.

Caroline Grillot is a Research Fellow at the Max Planck Institute for Social Anthropology in Halle, Germany.

\section{Notes}

1 On this specific topic, see Elena Barabantseva's article in this special issue of CrossCurrents.

2 The Zhuang are the most important native ethnic group of Guangxi (with a population of eighteen million, according to the 2010 Chinese national census), and the secondlargest ethnic group in China.

3 In the cases I have encountered, the ethnic identity of these men and women did not impact the questions they were facing regarding their administrative status.

4 The latest update (May 2015) indicates that in Móng Cái such a pass is now valid for twelve months, contains now a total of twenty-eight pages costs 50,000 VNĐ, and has slightly changed its name to bianjing diqu churujing tongxing zheng 边境地区出 入境通行证 (“immigration permit for borderland district").

5 According to two informants in Móng Cái and Lào Cai (private communications, January 2015), locals used to be able to easily get a national "travel pass" as well, at a lower cost $(200,000 \mathrm{VNĐ})$. But until recently, local authorities tended to refuse to provide such a document to borderlanders, requiring them to apply for the short-term "borderlanders' pass," a longer procedure. However, this pass gives its holder priority (no need to queue) when crossing the border during sensitive times with strict control of the frontier. Such procedures may vary from one border town or border province to another.

6 In human trafficking cases, the Vietnamese women who arrive in China often face immediate difficulties that go beyond the mere issue of administrative recognition. Their consequent vulnerability results from the deception they have experienced, lack of resources, loss of bearings, and absence of help from or solidarity with the families, 
villagers, and community members with whom they are constrained to stay (Grillot 2010).

7 "Viet Nam: Marriage and Family Law, 29 December 1986" (http://www.refworld.org/docid/3ae6b54dc.html), accessed January 29, 2015.

8 The Beilun River, which marks the border between China and Vietnam, is very narrow and easy to cross. Many migrants use the services of boat owners at night. Although illegal, it is a fast and relatively cheap option for crossing the border.

9 "Law on Residence, pursuant to the 1992 Constitution of the Socialist Republic of Vietnam, which was amended and supplemented under Resolution No.

51/2001/QH10 of December 25, 2001, of the 10th National Assembly, the 10th session"

(http://www.moj.gov.vn/vbpq/en/Lists/Vn\%20bn\%20php\%20lut/View_Detail.aspx?It emID=3710), accessed January 29, 2015.

10 There are no available and reliable statistics on the number of undocumented Vietnamese women currently living in China precisely because of the variety of their situations. Neither is there is any publicly available data on Vietnamese migrants who complied with the rules regarding international marriage.

11 "Marriage Law of the People's Republic of China, 1981" (http://www.npc.gov.cn/englishnpc/Law/2007-12/13/content_1384064.htm), accessed May 25, 2015.

12 Since I collected the data that informs this article, rules regarding the nationality of children born from at least one foreign parent in China have changed. The lack of any update on the situation of my informants (i.e., how these new laws have or have not affected their children's status) prevents me from analyzing the impact of such reform on the Sino-Vietnamese field.

13 Article 30: http://www.refworld.org/docid/3ae6b54dc.html.

14 Article 32: http://www.refworld.org/docid/3ae6b54dc.html.

15 Many of the couples I met in the borderlands previously lived in the countryside before choosing to settle in border towns, where they sought job opportunities and admitted enjoying relative impunity and flexibility regarding their marital situation. Hence, I suggest that border towns become the starting point but also the last spot on the migration trajectory of Vietnamese women, for this rather mobile social space allows a certain degree of invisibility. This is an estimation, since no available official quantitative data can support this statement so far.

16 I was not able to obtain consistent, reliable information on this policy and more precisely on its implementation in migration locations such as border towns.

\section{References}

Bélanger, Daniele. 2010. "Marriages with Foreign Women in East Asia: Bride Trafficking or Voluntary Migration?" Population \& Societies (English edition) 469: 1-4.

Bélanger, Daniele, Khuat Thu Hong, and Le Bach Duong. 2007. "Transnational Migration,

Marriage and Trafficking at the China-Vietnam Border." In Watering the

Neighbours's Garden: The Growing Demographic Female Deficit in Asia, edited by

Isabelle Attané and Christophe Z. Guilmoto, 393-425. Paris: CICRED.

Constable, Nicole. 2009. "The Commodification of Intimacy: Marriage, Sex, and

Reproductive Labor.” Annual Review of Anthropology 38 (1): 49-64. 
Coutin, Susan Bibler. 2003. "Illegality, Borderlands, and the Space of Nonexistence." In Globalization under Construction: Governmentality, Law, and Identity, edited by R. W. Perry and B. Maurer, 171-202. Minneapolis: University of Minnesota Press.

Evans, Grant, Christopher Hutton, and Kuah Khun Eng, eds. 2000. Where China Meets Southeast Asia: Social and Cultural Change in the Border Regions. Bangkok: White Lotus.

Greenhalgh, Susan. 2003. "Planned Births, Unplanned Persons: 'Population' in the Making of Chinese Modernity." American Ethnologist 30 (2): 196-215.

Grillot, Caroline. 2010. Volées, Envolées, Convolées... Vendues, en Fuite ou Re-Socialisées: Les "Fiancées" Vietnamiennes en Chine [Stolen, vanished, wedded... sold, runaway, or re-socialized: The Vietnamese "brides" in China]. Paris: Connaissances et Savoirs. . 2012a. "Cross-Border Marriages between Vietnamese Women and Chinese Men (Yunnan-Guangxi): The Integration of Otherness and the Impact of Popular Representation." In Wind over Water: Rethinking Migration in an East Asian Setting, edited by David W. Haines, Keiko Yamanaka, and Shinji Yamashita, 125-137. New York: Berghahn.

—. 2012b. "Between Bitterness and Sweetness, When Bodies Say It All: Chinese Perspectives on Vietnamese Women in a Border Space." Journal of Vietnamese Studies 7 (1): 106-148.

Hardy, Andrew. 2001. "Rules and Resources: The Household Registration Negotiating System in Vietnam under Reform." Sojourn: Journal of Social Issues in Southeast Asia 16 (2): 187-212.

Hsia, Hsiao-Chuan. 2007. "Imaged and Imagined Threat to the Nation: The Media Construction of the 'Foreign Brides' Phenomenon' as Social Problems in Taiwan." Inter-Asia Cultural Studies 8 (1): 55-85.

Huynh Chau Nguyen, Nathalie. 2009. "Vietnamese Women: Narratives of Cross-Cultural Marriages." Intersections: Gender and Sexuality in Asia and the Pacific 21: 1-13.

Jones, Gavin. 2012. "International Marriage in Asia: What Do We Know, and What Do We Need to Know?" Working Paper Series No. 174, Asia Research Institute, National University of Singapore.

Lafont, Pierre-Bermard, ed. 1989. Les Frontières du Vietnam: Histoire des Frontières de la Péninsule Indochinoise. Paris: L'Harmattan.

Lang, Graeme, and Josephine Smart. 2002. "Migration and the 'Second Wife' in South China: Toward Cross-Border Polygyny." International Migration Review 36 (2): 546569.

Lazzarino, Runa. 2014. "Between Shame and Lack of Responsibility: The Articulation of Emotions among Female Returnees of Human Trafficking in Northern Vietnam.|" Antropologica 1 (1): 155-167.

Li Juan, and Long Yao. 2007. "Zhong Yue bianmin kuaguo hunyin falü wenti tanxi” [Pondering on marriages of the cross-border people between China and Vietnam from a legal perspective]. Journal of Guangxi Administrative Cadre Institute of Politics and Law 22 (1): 71-74.

Li Juan, Luo Liuning, and Long Yao. 2007. “Renleixue shiye zhong de 'Wu guoji nüren': Yi Guangxi Daxin xian A cun weili" ["Women of no nationality" from an anthropological perspective: Taking A village of Daxin county in Guangxi as an example]. Journal of Baise University 20 (1): 7-14.

Luo Liuning, and Long Yao. 2008. "Zhongguo-Dongmeng jiagou xia Xinan bianjing kuaguo hunyin zinü de shehuihua" [Socialization of children from transnational 
marriages on China's southwest frontier]. Journal of South-Central University for Nationalities (Humanities and Social Sciences) 28 (1): 33-37.

Nguyen Thi Phuong Cham. 2014. "Cross-Border Brides: Vietnamese Wives, Chinese

Husbands in a Border-Area Fishing Village." Cross-Currents: East Asian History and Culture Review 11: 92-117. Available at https://cross-

currents.berkeley.edu/sites/default/files/e-journal/articles/nguyen.pdf, accessed June $1,2015$.

Peters, Heather A. 2002. Heaven is High and the Emperor is Far Away: Beijing Certainties Encounter Yunnan Ambiguities. Paper presented at "The Human Rights Challenge of Globalization in Asia-Pacific-US: The Trafficking in Persons, Especially Women and Children" conference, Honolulu, HI.Skalla, N. M. 2005. "China's One-Child Policy: Illegal Children and the Family Planning Law." Brooklyn Journal of International Law 30 (1): 329-363.

Toyota, Mika. 2008. "Editorial Introduction: International Marriage, Rights and the State in East and Southeast Asia." Citizenship Studies 12 (1): 1-7.

Turner, Sarah. 2010. "Borderlands and Border Narratives: A Longitudinal Study of Challenges and Opportunities for Local Traders Shaped by the Sino-Vietnamese Border." Journal of Global History 5 (2): 265-287.

van Schendel, Willem, and Itty Abraham. 2005. Illicit Flows and Criminal Things: States, Borders, and the Other Side of Globalization. Bloomington: Indiana University Press.

Vijeyarasa, Ramona. 2010. "The State, the Family and Language of 'Social Evils': ReStigmatising Victims of Trafficking in Vietnam." Culture, Health \& Sexuality 12 (S1): S89-S102.

Wang, Hong-Zen. 2007. "Hidden Spaces of Resistance of the Subordinated: Case Studies from Vietnamese Female Migrant Partners in Taiwan." International Migration Review 41 (3): 706-727.

Wang, Hong-Zen, and Shu-Ming Chang. 2002. "The Commodification of International Marriages: Cross-Border Marriage Business in Taiwan and Viet Nam.” International Migration 40 (6): 93-116.

Wang, Yi. 2005. Trafficking in Women and Children from Vietnam to China: Legal Framework and Government Responses. Quebec: Oxfam.

Womack, Brantly. 2000. "International Relationships at the Border of China and Vietnam: An Introduction." Asian Survey 40 (6): 981-986.

Yang, Wen-Shan, and Melody Chia-Wen Lu, eds. 2010. Asian Cross-Border Marriage Migration: Demographic Patterns and Social Issues. Amsterdam: Amsterdam University Press. 